\title{
Can we know God is real?
}

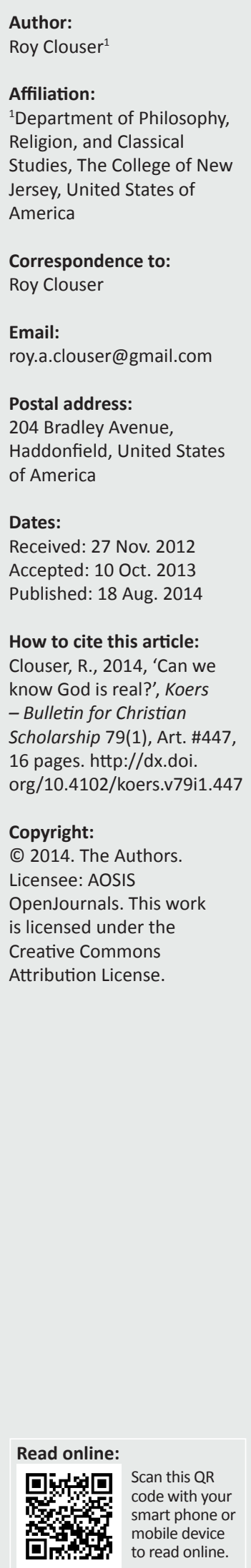

This article examines the question as to what ground we have for believing that God is the only true Divinity. A re-evaluation of the misconception of faith as 'blind trust' or belief without reason is provided. From this it is seen that faith, as used in the Bible, may refer to the whole of Christianity as 'the faith', to trust based on expectation (not 'blind trust'), or to faith as genuine knowledge derived from experience. Based on the idea of faith as knowledge derived from experience, this article investigates religious experiences and the self-evident beliefs often arising from these experiences as possibly forming a valid part of our knowledge of God. The traditional restrictions on self-evident truths (that a truth must be recognised by all who understand it, that it must be a necessary truth and that it must be an infallible truth) are shown to be unsupported and contradicted by experience. The definition of 'self-evidence' defended is that such beliefs are simply produced in the mind by experience instead of being inferred from other beliefs, that they are experienced as prima facie true, and that they are irresistible or impossible to disbelieve for the person who had the experience. If we accept this definition of self-evident truths, which corresponds to the way they are actually experienced rather than the version that includes arbitrary restrictions imposed by a few philosophers, not only will beliefs such as that other people have minds, or that our names are what they are, be allowed as self-evident. The experience of the gospel as the truth about God will also be a genuine self-evident truth to those who experience it as such.

Kan ons weet God is waarlik God? Hierdie artikel ondersoek die vraag na die gronde waaroor ons beskik om te glo dat God die enigste ware Goddelikheid is. 'n Herevaluering van die wanopvatting van geloof as 'blinde vertroue' of geloof sonder rede word verskaf. Hieruit kan gesien word dat geloof, soos dit in die Bybel gebruik word, na die hele Christendom as 'die geloof' kan verwys, dus, na vertroue wat op verwagting gebaseer is, en nie blinde vertroue nie; dit kan ook verwys geloof as kennis wat van ervaring afgelei is. Hierdie artikel maak gebruik van die idee dat geloof kennis is wat van ervaring afgelei word om ondersoek in te stel na die religieuse ervarings en die self-evidente oortuigings wat dikwels vanuit hierdie ervarings ontstaan as ' $n$ moontlik geldige deel van ons kennis van God. Daar word aangetoon dat die tradisionele beperkings wat op self-evidente waarhede geplaas word (dat ' $n$ waarheid deur almal wat dit verstaan erken moet word, dat dit 'n noodsaaklike waarheid moet wees en dat dit ' $n$ onfeilbare waarheid moet wees) nie oortuigend is nie en nuwe kriteria word voorgestel. 'Self-evident' is dan oortuigings wat eenvoudig deur ervaring in die verstand geproduseer word en dit is vir die persoon wat die ervaring beleef onmoontlik of onweerstaanbaar om die oortuigings nié te glo nie. Indien ons hierdie definisie van self-evidente waarheid, wat ooreenstem met regte ervaring eerder as met daardie weergawe waarin arbitrêre beperkings deur 'n paar filosowe voorgeskryf word, aanvaar, sal nie net oortuigings soos dat alle persone ' $n$ verstand het of dat ons name is wat dit is, as self-evident aanvaar word nie. Ook die ervaring van die evangelie as die waarheid omtrent God sal as 'n egte self-evidente waarheid aanvaar kan word deur diegene wat dit as sodanig ervaar.

\section{Author's preface}

The article that follows is written from a frankly Christian point of view. It does not seek to prove that God exists or that Christianity is true, as both are assumed from the outset. It is also written for Christians in that its focus is on whether Christian faith has the status of knowledge or is something less than that. I argue that it is, indeed, knowledge whenever some significant cluster of Christian beliefs is experienced as self-evident and that cluster includes or presupposes God's reality. Whenever that happens, those beliefs are justified and so count as knowledge, not blind trust. Moreover, I argue that this is a paraphrase of a teaching found in the New Testament (NT) itself. 
This conclusion is not, however, presented as a proof of God's existence. In fact, I argue that God's existence cannot be proven - though it can be known. Nor am I assuming that knowledge must be defined as justified true belief. Including the truth of a belief in the definition of knowledge is analogous to defining veridical perception as normal perception of something that really exists. In both cases it can only be more of the same kind of experience that first produced a belief or a perception that could possibly provide the criteria for determining that the belief is true or the perception is veridical. Thus including the truth of a belief in the definition of knowledge makes every knowledge claim either hopelessly circular or entangled in an infinite regress. For these reasons I take knowledge to be justified belief, and argue here that the experience of a belief's self-evidence counts as justification.

\section{The Christian view of the grounds of belief in God}

\section{Faith}

The question taken up in this essay can be posed this way: On what ground do we believe that the only true Divinity is the Triune Creator God who manifested himself incarnate in Jesus Christ? Often the first answer I get is: 'Belief in God's reality is a matter of faith; we take it on faith that God exists'. And because this is such a widely accepted answer, it is all the more important to see right away why it is sorely in need of clarification.

This clarification is necessary because there are so many misunderstandings about the meaning of the word 'faith' as it is used in connection with religious belief. For example, Mark Twain once quipped that 'Faith is believin' what you know ain't so' and many other writers have done almost as badly. 'Faith' has been defined as 'belief beyond the evidence', or even 'belief despite the evidence', and it is widely assumed to mean blind trust by which someone takes a 'leap of faith'. So it is important that we take some time to see how the writers of the New Testament use the term.

The first clarification is that they never use 'faith' in any of the senses just mentioned. No one can possibly believe what he or she knows to be false, and no New Testament writer uses 'faith' to mean belief against evidence, belief beyond the evidence, or a blind 'leap of faith'.

The second clarification concerns the way the meaning of the term 'faith' was transformed by New Testament writers. Every writer of the New Testament was, so far as we know, an observant Jew who had come to believe that Jesus was the promised Messiah. Not surprisingly, they all show great familiarity with the Old Testament (OT). But the term 'faith' appears only once in the entire Old Testament! That single occurrence is in the prophet Habakkuk, where he says: 'The just shall live by faith.' By way of contrast, the New Testament, which is less than one-quarter the size of the Old Testament, uses the term 'faith' at least 245 times. How are we to understand this difference? Why do New Testament writers make prolific use of a term that had played almost no role in their religious life prior to becoming Christians?

The need for a new term for religious belief was the same need that required those authors to write in Greek rather than in Hebrew: the gospel of Jesus Christ was to be good news not only for Jews but for the entire gentile world as well. For that reason, the record and interpretation of the life and work of Christ needed to be in the international language of that day, which was Greek. Moreover, it needed a term for religious belief that did not assume the hearers of the gospel message were already familiar with the history of God's dealings with Israel. It had to challenge gentile pagans whose general outlook on religion was enormously different from the way it was thought of in Israel.

In Israel God was known to his people by his mighty acts which were both recorded and interpreted by its priests, scribes and prophets. That is why Old Testament writers refer often to God being known to Israel by his presence amongst them. There was nothing speculative about that knowledge; it was not a theory they proposed to explain anything, but reports of Israel's experiences of God's covenantal care. For the observant Jew, belief in God was what we would now call belief by acquaintance. God's presence was constantly experienced in a variety of ways, and the stories of his past saving actions were woven into the very fabric of Israel's national consciousness. There were, for example, God's appearances to the Patriarchs, his mighty deliverance of Israel from Egypt, his leading the people by a pillar of cloud and a pillar of fire, and the miracles performed by the prophets. Most important of all was God's constant and continual presence in the holiest place of the Temple above the Ark of the Covenant. Israel knew God because God lived with Israel. ${ }^{1}$

In this setting it made sense for the prophets to call for faithfulness, to issue reminders of what Israel owed God in return for his covenant-love. But there was no need for a distinct term for religious belief such as 'faith'. Israel's belief in God was never mere belief, but belief that was also knowledge in the sense of an intense experiential relationship. In fact, the same term was used in Hebrew for knowing God as was used for conjugal relations of husband and wife (Gn 4:1: 'And Adam knew his wife and she conceived ...'). So there was no debate in Israel concerning whether God's reality could be known, as opposed to whether it was mere speculation or opinion. By way of contrast, that was exactly the debate which had occupied Greek and Roman poets and philosophers for hundreds of years prior to the rise of Christianity. In Greece, the ultimate 'wisdom' about religious belief was Protagoras' famous comment: 'Concerning the gods, it is not possible to know whether they are or are not ...' By contrast, in Israel the verdict on the same subject was: 'The fool has said in his heart "There is no God"' (Ps 14:1, 53:1).

1.Israel also experienced God's absence, of course, as that is lamented in the Psalms, Job and Jeremiah. But God's absence can be lamented only because it is contrasted with his presence. 
In the debate over what counts as knowledge, Greek philosophers had developed a specific terminology for highlighting the difference between beliefs that are merely opinions and beliefs we have the intellectual right to say are certainties. From Plato onwards the terminology used was to call beliefs we are entitled to be certain of 'episteme' [knowledge], whereas the term 'pistis' [opinion] was reserved for mere opinions no one is entitled to be certain of.

I'm not suggesting that Jews were not every bit as much aware of the difference between mere opinion and certainty as the Greeks and Romans (it occurs in Jos 23:13, for example). The difference between belief that is merely opinion and belief that is certain knowledge is a common one. No one has to be a philosopher to be aware that often we are justified in being sure of a particular belief, and to be equally well aware that at other times beliefs we hold are merely opinions we trust to a lesser degree than certainty. I like the way this point was put by one of my favourite mystery writers: 'There's knowing and there's knowing for sure and there's a space between the two of them a man can get lost in' (Hill 1998:353).

For example, the belief that you will go to bed before 10 o'clock tonight or that next month will be unusually sunny are merely opinions. They may turn out to be true, but you have no good reason to be certain of them in advance. Other beliefs we are not justified in being certain of are promises we take on trust. If a friend promises to keep a secret, we can't be completely certain the promise will be kept until it has been. Many of the beliefs we accept on the say-so of others are in the same boat, such as your belief in the accuracy of a friend's report of a car accident you did not witness.

From now on I will refer to the opinions we form, including promises we take on trust, as beliefs we accept rather than as beliefs we know. I will use 'know' only for the ones we are justified in being sure of beyond a reasonable doubt. On this use of the terms your belief in a friend's account of the car accident is an opinion you accept, whereas your belief that in the natural number series $1+1=2$ or that you are now seeing these words on this page is knowledge.

Since this is a commonly recognised distinction, it should not surprise us that the writers of the New Testament (especially St Paul, St John, St Luke and the author of Hebrews) were also aware of the difference between opinion and certainty. Moreover, there is no reason to suppose they were unaware that it had played a large role in the history of pagan thought about religion. Thus it should also not surprise us that they needed a new terminology which would differ sharply from the pagan intellectual tradition and at the same time communicate the Jewish (and now Christian) view of religious belief to those whose thinking had been formed by that pagan tradition.

In the dominant pagan Greek intellectual tradition, the only beliefs that were certain (episteme) were those which are either self-evident or proven, and the only beliefs that were allowed as self-evident were (with a few exceptions) the truths of logic and mathematics. In contrast, what we find in the New Testament completely ignores the dichotomy of episteme and pistis that had been developed by pagan thinkers. The term episteme occurs only four times and never means certainty as contrasted to mere opinion. ${ }^{2}$ What those writers did was to transform the term 'pistis' (translated as 'faith') into a term for religious belief generally, and then use it in three specific senses.

\section{The three senses of 'faith' in the New Testament}

One of these senses, entirely new to the Greek language, was that they used 'faith' (pistis) to refer to the whole of the Christian religion - to all that God had revealed. This is what we find whenever they use it as a noun referring to Christianity as 'the Faith'. It occurs, for example, in such expressions as: 'the Faith once delivered to the saints' (Jude 3) or '... continue in the Faith firmly established ...' (Col 1:23).

The second sense for the term in the New Testament is a little bit closer to the Greek meaning of 'mere opinion', and is also the sense that is closest to the way we most often use 'faith' in a non-religious context today. In this second sense, 'faith' means trust in someone. It is the sense used when New Testament writers admonish us to trust God to keep his promises, and when they praise believers of the past for having done so. For example: 'For we walk by faith not by sight ...' (2 Cor 5:7) and '... all these died in faith without having received the promises ...' (Heb 11:13).

The way this is 'a bit closer' to the traditional Greek usage is a subtle point. St Paul and the author of Hebrews both take it that when God makes a promise we have every right to be confident that it will be fulfilled. Nevertheless, they both still regard that confidence as something less than the complete certainty that would come from actually seeing the promise fulfilled. So what Paul says amounts to: We 'walk' (conduct our lives) by 'faith' (trust in the promises we know God has made) not by sight (not yet having seen the promises fulfilled). Behind this distinction lies an even more stringent criterion for certainty than many modern theories of knowledge have demanded. ${ }^{3}$ Still, it does not leave this second sense of 'faith' as mere opinion or blind trust. Instead, it is expectation based on a promise where the promisor is God but the promise has not yet been fulfilled. Thus it is confident expectation for a reason. In fact, it is expectation that is justified by the best possible reason short of directly witnessing the promise fulfilled.

Moreover, Hebrews adds even more to the reason behind this second sense of 'faith'. Besides pointing out that it is God who has promised something, Hebrews 11 makes clear that the ground on which we are urged to rely on God's promises for the future is his record of having been faithful to them in the past. So even the second sense of 'faith' never amounts to

2.It is also never used by St Paul, who is the primary author of the new senses of 'faith'. The four loci are: Acts 10:28, 15:7, James 4:14, and Jude 10. Paul is not alone in using the new senses of 'faith', however. The author of Hebrews and St John also in using the noy them.
employ

3.John Locke (1959:383), for example, took a promise from God as a certainty: 'We mohn Locke (1959:383), for example, took a promise from God as a certainty: 'We
may as well doubt of our own being, as we can whether any revelation from God be may as well doubt of our own being, as we can whether any revelation from God be
true. So that faith is a settled and sure principle of assent and assurance, and leaves no manner of room for doubt or hesitation'. 
a 'leap in the dark'. Instead, Bible writers always admonish us to trust God's promises for the same reason we would trust another human being to keep a promise: the promisor's past record of faithfulness.

But the New Testament writers also use 'faith' in a third way, a sense which moves the entire matter of religious belief in line with their Jewish background. In this third usage it means belief that is also knowledge in the sense of certainty derived from experience.

For example, St Paul chides some of the members of the church at Galatia for thinking they must earn their salvation by keeping religious regulations. In rebuttal he asks them: 'Did you receive the Holy Spirit by hearing [the gospel] with faith or by the works of the Law?' There the term 'faith' cannot mean trusting in God's promises, since the good news that the Messiah has come is not merely a promise at that point but an accomplished fact. Nor is it a noun naming the Christian religion as a whole. It can refer to nothing else than belief in God's reality and to the truth of the claim that God offers salvation in the gospel. It is significant, then, that this very same belief is often referred to as 'knowledge' elsewhere in the New Testament, reflecting the Old Testament expression 'the knowledge of God'.

Another place where the term 'faith' is used to mean belief that is certain is Hebrews 11. There we are told: 'Without faith it is impossible to please [God], for whoever would come to him must believe that he exists and that he rewards those who seek him' (Heb 11:6). This same belief, however, is also described elsewhere as 'trustworthy and deserving of full acceptance' (1 Tm 1:15), and equivalent to knowing God (Jn 17:3; 1 Cor 8:6, 7; 1 Jn 4:16). Those who have faith in this sense are spoken of as ones who 'believe and know the truth' (1 Tm $4: 3)$, so it is clear that this third sense of 'faith' is not mere belief but belief which is also certainty. The same is true of Peter's confession in John 6:69: 'Lord to whom shall we go? You have the words of eternal life. And we believe and know that you are the Christ, the Son of God.'

For these reasons the statement quoted from Hebrews 11:6 should be seen as starting with the third sense of faith and proceeding to the second sense. The faith in God's existence is certain knowledge, whereas the faith that he rewards those who seek him is trust in God's promises. ${ }^{4}$

This third use of 'faith' is so unlike our common English usage now that it can easily be missed. In ordinary speech we never use that term to mean that we are certain of something, but New Testament writers do. The reference to 1 Timothy $4: 3$ is only one of a number of times they speak about Christian teachings which are matters of faith

4.This difference was also recognised by the famous commentator on Hebrews Franz Delitzsch. Delitzsch says that belief that God exists is 'the faith of assured Franz Delitzsch. Delitzsch ravs that belief that Godexists is 'the faith of assured conviction', whereas belief that he of confident expectation'. This corresponds to my third and second senses of 'faith', assuming that Delitzsche used 'assured' as a synonym for 'justified' (Delitzsche 1952:230). in the sense that they are teachings 'we believe and know'. Moreover, neither the New Testament authors nor any writers of the Hebrew Bible ever speak of the belief that God is real as faith in the sense of mere opinion or hope. Rather, they always speak of it as knowledge we are entitled to be certain of.

\section{Other Christian thinkers who saw this point}

Unfortunately, there are a number of prominent Christian thinkers who missed this point. Nevertheless, there is also a significant tradition of others who did not miss it. In fact, these thinkers not only recognised that New Testament writers use this third sense of 'faith', but they employed it the same way in their own writings, making clear that they use it as equivalent to sure and certain knowledge. For example:

Gregory of Nyssa:

[Faith] makes the invisible our own, assuring us of the imperceptible by its own certainty about it. (Pelikan 1992:217) (emphasis added)

Gregory Naziansus:

Faith is what gives fullness to our reasoning. (Pelikan 1992:27)

Basil of Caesarea:

Knowledge of the divine essence involves perception of its incomprehensibility, and the object of our worship is not that of which we comprehend the essence, but of which we comprehend only that the essence exists. (Pelikan 1992:302) (emphasis added)

Luther:

Faith is a living, bold trust in God's grace, so certain of God's favor that it would risk death a thousand times trusting in it. Such confidence and knowledge of God's grace makes you happy, joyful and bold in your relationship with God and all creatures. The Holy Spirit makes this happen through faith. (Luther, 1854, 125) (emphasis added)

Calvin:

For faith includes not merely the knowledge that God is, but, also, nay chiefly, a perception of his will toward us. (Calvin 1953, III:ii, 6)

But the human mind, when blinded and darkened is very far from being able to rise to a proper knowledge of the divine will ... Hence, in order that the word of God may gain full credit, the mind must be enlightened ... from some other quarter. We shall now have a full definition of Faith if we say that it is a firm and sure knowledge of the divine favor toward us, founded on the truth of a free promise in Christ, and revealed to our minds, and sealed on our hearts, by the Holy Spirit. (Calvin 1953, III:ii, 7) (emphasis added)

Pascal:

By faith we know [God's] existence ... (Pascal 1960:93) (emphasis added)

To sum up, the term 'faith' is used in the New Testament to mean:

1. The Christian religion as a whole.

2. Taking God's promises and other revealed information

5.Luke 1:4; John 6:69; Acts 12:11, 22:30, 25:26; I Timothy 2:4, 4:3; I John 2:3, 4:16 $5: 13$. Some of these simply take notice of the difference between opinion and knowing for certain, but others of them also apply that difference in order to say that we not only believe but 'know' God and the truth of the gospel. 
on trust. This is not blind faith, however, because it is based on God's record of past covenant faithfulness.

3. Belief that God is real and offers us the gospel, in which case faith means we both 'believe and know'.

But if believing that God is the one and only divine Creator is faith in the third sense, the sense that is actually equivalent to knowledge, what is it that justifies this certainty and how do we come to acquire it?

The New Testament actually answers these questions quite clearly despite the fact that a myriad of writers on the subject have preferred to ignore what it says and to construct their own theories about it instead. (I am not suggesting that the NT actually attempts to give a full account of religious knowledge, let alone an entire epistemology. But it teaches more that needs to be included in any epistemology than the majority of writers on the subject have recognised.) The New Testament's own answer is that we know God is real by experiencing God. With the addition of this point, the third sense of 'faith' completes the project of replacing the pagan gentile outlook on religion with the Jewish-Christian understanding. ${ }^{6}$

\section{Religious experience}

The New Testament explicitly mentions a number of different ways people can and do experience God, and there are even more ways this happens than those it explicitly mentions. For example, the book of Acts tells of the experience of Saul on the road to Damascus. In fact, however, that experience is not unique. Take the case of Sadu Sundar Singh. Singh had been a devout Sikh all his life. Eventually he became discouraged with Sikhism and set out to find God, and he did so with the pre-conviction that anything might be the truth except Christianity. Early one morning, he says:

In the room where I was praying I saw a great light. I thought the place was on fire .... Then the thought came to me that this might be an answer that God sent me. Then as I prayed and looked into the light, I saw the form of the Lord Jesus Christ ... whom I had been insulting a few days before .... I heard a voice saying in Hindustani 'How long will you persecute me? I have come to save you; you were praying to know the right way. Why do you not take it?' ... [So] I fell at his feet and got this wonderful peace which I could not get anywhere else. (Streeter \& Appasamy 1921:5-7)

Another sort of experiencing God, one that is not mentioned in the New Testament, is one in which nothing is seen or heard but God's presence is sensed. There are many such reports over many centuries that are amazingly alike, but here is a contemporary one that was related to me by the person who had it:

I was alone for the evening and decided to try reading the gospel of John as you suggested, convinced it could make no difference to my skepticism about God. I picked up the Bible, turned to John, and suddenly I was over- whelmed by a presence that filled the room. I closed the book and decided my mind was

6.It is impossible to say to what extent this 'project' was self-conscious, but it could have been. The writer whose work most evinces it is St Paul, who was conversant
with the Greco-Roman intellectual tradition, quotes their poets, and even refers to philosophy (Col 2:8) playing tricks on me. I'd get a shower, calm down, and come back to it. I felt foolish at being spooked. 'It's just a book!' I said, laughing. But when I tried to read again the presence was more over-powering than before. It wasn't threatening. In fact it was powerfully loving. But I threw the Bible across the room and yelled, 'Go away and leave me alone! I like my life the way it is!' Yet it persisted, and when I tried again to read the gospel it all looked undeniably true. (James 1929)

There are yet other sorts of experiences of God besides visions and the sense of God's presence, such as that of a mystical union - a oneness with God that is literally indescribable. There are also instances in which ordinary events become transparent to their dependency on God, or are experienced as revealing God's will. It is not important to the certainty of the beliefs generated just which type of experience generates them, any more than it matters precisely what the contents of the experiences are. No matter whether the avenue of experience is ordinary perception (sight, touch, sound, smell, taste), extraordinary perception (a sense of God's presence, or mystical union), memory, reflection, or whatever, the crucial point is that the experience generates a belief that is prima facie and irresistibly true to the person who has it.

That this is equivalent to such a belief's being self-evident has been consistently missed in discussions of religious experience. Even William James's monumental work, The varieties of religious experience, failed on this point despite how close James came to seeing it. James (1929) says of the stranger experiences:

One may indeed be entirely without them, ... but if you do have them at all strongly, the probability is that you cannot help regarding them as genuine perceptions of truth, as revelations of a kind of reality which no adverse argument, however unanswerable by you in words, can expel from your belief. (pp. 72-73)

No doubt he stopped short of recognising this as a description of self-evidence owing to the traditional restrictions the western intellectual tradition had placed on what may count as self-evident.

\section{The experience of self-evidence}

Missing this point is also why Thomas Hobbes got things exactly wrong when he quipped: 'When a man says God spake to him in a dream he says no more than that he dreamed God spake to him'. What Hobbes missed is precisely that quality of an experience which philosophers have long called 'self-evidence'. That is the feature of any experience-dreams included - that can justify the person having the experience in the belief that it is communication from God.

It is a fact that believers often experience God's presence, nearness, comfort, judgement, encouragement, and the like, in a wide variety of ways, each of which includes that it is self-evident it is God who is experienced. That said, it remains true that amongst all the varied experiences, there 
is one particular type of experience that is primary over the others: the experience of encountering God through his word as recorded in scripture. This is the primary sense of religious experience because: (1) whether or not a person has any of the more unusual experiences (and most believers do not), every Christian experiences as self-evident that the gospel is the truth about God from God, and (2) it is scripture that provides the basis for the interpretation of the other sorts of experience.

As you can see, then, on this view an experience isn't religious only if it is miraculous or very strange. Rather, $a$ religious experience is any experience that generates, deepens or confirms a religious belief. The question that is always posed by critics is whether such experiences not only generate but can justify that belief. The answer I'm proposing is: Yes, if the belief generated is experienced as a self-evident truth.

Both the Old and the New Testaments speak of just such experiences, and do so by using the same visual metaphors for self-evidence that philosophers, mathematicians and logicians have long used. The Psalmist remarks upon the experience of seeing the truth when he says 'in your light we see light' (Ps 36:9), and 'your light is truth' (Ps 43:3). This is continued by the New Testament's talk about 'the light of the gospel' shining in our hearts (Jn 1:6-9; Acts 26:17, 18; Rm 11:8, 10; 2 Cor 4:4, 6; Eph 5:8, 9; 1 Pt 2:9) and about our hearts having been previously 'darkened' because we were born 'blind' to the truth about God (Mt 13:13-16; 15:14; Mk 8:17, 18; Jn 9:39). Most telling of all is the expression St Paul uses in Romans 1:21 and Ephesians 1:18, where he speaks of our being 'enlightened' by the Holy Spirit so that we 'see' God's truth with 'the eyes of our mind' (the term in Greek is actually 'heart' not 'mind').

Paul doesn't explicitly use the expression 'self-evident' here. But by insisting that people come to know God when his Spirit opens their hearts so that they 'see' for themselves the truth of the gospel, he is using the same language that the leading thinkers of the Pagan world had used for centuries to talk of beliefs that are self-evident and therefore selfjustifying. At the same time, he and other New Testament writers transformed the scope of what had been allowed as self-evident in the pagan philosophical tradition. Instead of self-evidence being confined to truths of mathematics and logic (and a few metaphysical principles), the New Testament writers take it to refer to all the varied experiences by which human beings encounter God, including those by which 'his Spirit bears witness with our spirit that we are the children of God' (Rm 8:16).

At this point some readers may be tempted to object to identifying any type of religious experience as self-evident. It may seem to them that self-evidence is a highly abstract idea that arose in the context of such lofty endeavours as mathematics, logic and philosophy. For that reason it could seem highly artificial to introduce it into the sweaty realm of actual lived experience - and religious experience at that!

However plausible this objection might at first appear, it actually gets things backwards. If we have learned anything from Wittgenstein, it should at least be that the experience of certainty that needs no justification is part of our everyday lives. It is an experience that first arises in our lived engagement with the world around us, and not in the context of abstract theorising. As he says in On certainty:

358. Now I would like to regard this certainty, not as something akin to hastiness or superficiality. But as a form of life. (That is very badly expressed and badly thought as well.) 359 . But it means that I want to conceive it as some-thing that lies beyond being justified or unjustified; as it were, as something animal. (Wittgenstein 1972:46e, 47)

My point is that those engaged in theoretical enterprises recognised in them states of affairs that had a certainty like that of their pre-theoretical experience. They borrowed the idea of that certainty, re-christened it 'self-evidence', and then attempted to kidnap it by declaring it to be solely the property of abstract truths. The New Testament position concerning the certainty of the experience of God therefore returns that experience to its pre-theoretical home ground. My proposal, then, is that this transformed idea of selfevidence is therefore the right way to understand the Jewish-Christian talk about God opening a person's heart so that the person 'sees' the truth of God's word. And the New Testament's talk about God removing a person's spiritual blindness so that he or she can 'see' the gospel to be true means that it becomes self-evident to that person that the gospel is the truth about God from God. Thus, when a cluster of scripture teachings is experienced in this way, that is equivalent to hearing God speak.

It is this position that should be taken as the New Testament's answer to the usual sceptical questions about the more unusual experiences mentioned above. They are often attacked as being pathologies such as hallucinations, etc. The proper reply to these attacks concerns itself with the selfevidence of the beliefs conveyed, and ignores the debates about the state of the experiencer. Debates over whether the experience was veridical or not go nowhere: those who deny God's reality will never admit that any such experiences really come from God, whereas those who believe in God because of such experiences will never be shaken in their conviction that they came from God. The position developed here circumvents these debates.

This position should also be viewed as the New Testament's reply to such sceptical questions as, 'How did Abraham (or Moses or Jesus) know it was God who was talking to him?' And it also answers the question how we can know the Bible is the record of the covenants God made with human beings. In each case the beliefs in question are justified by the experience that it is self-evident that it is God who has made himself known.

One last consequence: on this position, belief in God's reality is not a theory, and therefore needs no proof. Whatever we experience as self-evident doesn't need proof; it is theories - educated guesses - that need evidence and proof. 


\section{Two Christian writers who have seen this point}

I have already taken note of the way many writers have preferred to ignore what the New Testament has to say about the grounds for belief in God when constructing their theories of religious belief. But I will now quote two thinkers who did not ignore the New Testament on this topic, but captured and expressed its teaching beautifully. One of these is a theologian and Protestant; the other is a scientist and Catholic. The first is from John Calvin:

As to the question, How shall we be persuaded that [scripture] came from God ... it is just the same as if we were asked, How shall we learn to distinguish light from darkness, white from black, sweet from bitter? Scripture bears upon the face of it as clear evidence of its truth as white and black do of their color, sweet and bitter of their taste. (Calvin 1953, I:vii, 2)

... [unbelieving] men think that religion rests only on opinion and, therefore, that they may not believe anything foolishly, or on slight grounds, desire and insist to have it proved by reason that Moses and the prophets were divinely inspired. But I answer that the testimony of the Spirit is superior to reason. (Calvin 1953, I:vii, 4)

... Scripture, carrying its own evidence along with it, deigns not to submit to proofs and arguments, but owes the full conviction with which we ought to receive it to the testimony of the Spirit of God .... (Calvin 1953,I:vii, 5)

Such, then, is a conviction that asks not for reasons ... a knowledge which accords with the highest reason, namely, knowledge in which the mind rests more securely than any reasons ... I say nothing more than what every believer experiences in himself though my words fall far short of the reality. (Calvin 1953, I:vii, 5)

The second is from Blaise Pascal (1960):

We know truth not only with the reason, but also with the heart. It is in this latter way that we recognize first principles, and it is in vain that reason, which has no part therein tries to impugn them ... For the knowledge of first principles - for example space, time, motion, and number, [is] as sure as any of those procured for us by reason. And it is upon this knowledge of the heart and instinct that reason must rely and base all its arguments ... Those, therefore, to whom God has imparted religion by intuition are very fortunate and very rightly convinced. ${ }^{7}$ (p. 22)

So we may perfectly well know that God exists ... by faith we know his existence; in the light of glory we shall know his nature. (p. 93) (emphasis added)

These two writers make essentially the same point: The truth that God is real and has made covenant promises to human beings can be known by direct experience. Calvin holds that once the Spirit of God removes the blindness of a person's mind, seeing the truth of the gospel is analogous to the selfevidence of normal sense perception. Pascal, on the other hand, calls the experience an 'intuition' of truth and compares it to recognising the self-evidence of 'first principles' (axioms).

Keep in mind that for these thinkers, as for the New Testament writers, belief in God is not knowledge merely in the sense

7.Pascal's contrast here between the intuition of first principles with 'reason' uses the latter term in the sense of reasoning. Obviously the intuition of rational first principles is part of reason broadly construed. of intellectual assent. The experience of 'seeing' the truth about God is the result of the work of God's Spirit performed in the heart of the enlightened person where 'heart' is used in the biblical sense of that term. For Bible writers, I remind you, 'heart' does not refer to emotion rather than intellect but to the central unity of a human being. So whereas you or I are used to speaking of head knowledge as opposed to heart knowledge and use such expressions to mean intellect as opposed to feeling, the Bible writers speak of the human heart as the unity of intellect, emotion, will, talents, dispositions and all else that makes up a person. ${ }^{8}$ For this reason, when the heart is enlightened, the intellect sees the truth 'with the eyes of the heart' and so knows God, whilst the emotions are turned towards God in love, and the will is inclined to please him. This is why enlightenment by God's Spirit is called 'conversion' - the re-direction of the whole person. The whole person was lost to the sin of belief in a false god, and the whole person is now initiated into the process of being restored to a proper relationship with the true and living God. This is never merely intellectual, but is seated in the deepest dispositions of the heart - the centre of human existence. To sum up once more:

1. Faith that God is real and has made covenant promises to human beings is not a matter of trusting a promise, let alone blind trust; rather

2. It is self-evident knowledge acquired by direct experience, which is why

3. Faith that God is real and offers us the gospel is neither a theory nor in need of proof.

4. Faith in God, by contrast, goes beyond knowing God is real. It is taking God at his word concerning the promises and other truths he has revealed, and results in striving to obey his commandment to love him with all our heart, soul, mind and strength, and our neighbour as ourselves.

\section{The meaning of 'self-evident'}

Most people are acquainted with the term 'self-evident' only from the famous lines of the American Declaration of Independence: 'We hold these truths to be self-evident, that all men are created equal and have been endowed by their Creator with unalienable rights ....' So the first thing that needs to be said is that the Declaration used 'self-evident' in a way that is partly right but partly wrong. In philosophy, mathematics and logic it had long been recognised that a selfevident belief is one whose truth is so obvious that no proof is necessary. It is a belief that is not inferred from any other belief, is prima facie true, and is irresistibly true. Thus there is no point in debating it.

The part the Declaration deliberately ignored is that self-evident truths are defined as truths that are not derived from any other

8.This also includes, of course, the exercise of trust or faith. Acts of faith are motivated by the dispositions of the heart, and are good indicators of its dispositions. Thus what a person trusts unconditionally reflects his or her divinity belief because only what exists unconditionally could be unconditionally trustworthy. Luther captured what exists unconditionally could be unconditionally trustworthy. Luther captured this point when he wrote: What does it mean to have a God? As I have often said, the trust and faith of the heart alone make both God or an idol. If your faith and trust are right then your God is the true God ... if your trust is false and wrong, then you have not the true God. That to which your heart clings and entrusts itself is, say, really your God'. (Luther 1959:365). Where a belief is in two (or more) divine principles, each is trusted as unconditionally real. For example, Aristotle had to admit that although matter was not changeless, it (as well as form) was nevertheless 'substance' just because it is self-existent (Meta 1026a and 1036 a). 
beliefs, for the belief in the legal equality of all human beings and that they possess rights was unquestionably derived from the Bible. It is an inference from the doctrine that all human beings are created in the image of God. In fact, the first draft of the Declaration acknowledged that when Jefferson wrote: 'We hold these truths to be sacred and undeniable'. The term 'sacred' was his allusion to the biblical roots of the idea that all human beings have rights. But Franklin talked him into changing 'sacred and undeniable' into 'self-evident', which had two effects: it removed even the oblique reference to the biblical roots of the idea of equality and rights, and it conveyed the implicit claim that such rights were truths obtainable from reason alone (from rational self-evidence) without the aid of revelation. That is why those truths were supposed to be beyond debate.

The fact is, however, that neither Jefferson nor Franklin really thought that the equal worth of all human beings was not derived from the biblical teaching that all are created in the image of God. Nor did they think that the equal rights of all people was a truth as obvious to everyone as $1+1=2$. The appeal to self-evidence was intended to convey this message to King George III: We won't debate this with you even if you disagree and think others are not equal to you because you are a king. ${ }^{9}$

With that mistake out of the way, I propose that the proper definition of the experience of self-evidence goes like this:

A belief, $\mathrm{B}$, is self-evident to a person, $\mathrm{P}$, if and only if:

1. $B$ is directly produced in $P$ by experience and is not believed by inference from other information ${ }^{10}$

2. B is experienced by $\mathrm{P}$ as prima facie true, and

3. B is initially irresistible to $\mathrm{P}$.

Each of the items in this definition will be explained shortly.

\section{The traditional restrictions on self-evidence}

Now the claim that God's reality can be self-evident to anyone will appear outrageous to those acquainted with the history of that idea in Western philosophy. Here's why.

The Grand Masters of the Western intellectual tradition concluded long ago that a belief is genuine knowledge rather than mere opinion provided it is either self-evident or proven. ${ }^{11}$

9.This is not to suggest that there is no difference whatsoever between the selfevidence of $1+1=2$ and that of God's reality. Arithmetical truths are simpler and clearer than ethicaltruths or divinity beliefs. My wife's existence is also self-evident to me, but beyond that it has all the vagaries of any personal relationship. Our relation to God is similar; whilst his reality is no less
of our relationship with him has its ups and downs.

10. Notice that I did not say it can't be inferred, since any belief can trivially be made the conclusion of an inference. Rather, it means that it is not in fact believed on the grounds of inference from any premises which could entail it or show it probable.

11. See Aristotle's Posterior analytics 72, b 5-24; 75 a 31-32. Aristotle's point that self evident knowledge is basic to all proof has been denied at times, but even those denials inevitably end up appealing to self-evidence at some point. For example, E. Nagel (1954:304) ridiculed it as the idea that 'there must be transparently luminous universal truths which the intellect grasps as self-evident', and tried to substitute pragmatic utility in its place. And Stephan Barker even rejected self-evidence as the pragmatic utility in its place. And Stephan Barker even rejected self-evidence as the
proper access to logical laws. He derided the experience as 'a kind of penetrating proper access to logical laws. He derided the experience as 'a kind of penetrating
and occult clairvoyance' by which we succeed in 'gazing into the abstract innards of the universe' (Barker 1974:297). But how can Nagel know whether a principle is of the universe' (Barker 1974:297). But how can Nagel know whether a principle is
a pragmatic success or Barker know that a rule of logic 'holds true in virtue of the a pragmatic success or Barker know that a rule of logic 'holds true in virtue of the
ways words are used' (p. 301) unless those things are self-evident to them? For a ways words are used' (p. 301) unless those things are self-evident to them? For
detailed critique of the pragmatist rejection of self-evidence (see Clouser 1997).
That seems to me too narrow a definition in a number of ways, but there is not the room here to critique the whole of this traditional view. For now I will focus only on how it handled self-evident knowledge. This is important both because its teaching about self-evident truth is false and because it has been remarkably dominant for more than 2300 years. For whilst it might at first sound as though its view is congenial to belief in God since it allows that selfevidence justifies a belief, thinkers such as Aristotle and Descartes not only acknowledged self-evidence but also put restrictions on it. And those restrictions rule out belief in God as genuinely self-evident - which is why Christians have so often been asked for proof that God is real. So if the New Testament position is to stand up, those traditional restrictions must be shown to fail.

Before I do that, however, I want to explain why the other part of their idea of what justifies a belief - the requirement of proof - is a serious mistake with respect to God's reality. This is an important point because so many Christian thinkers accepted the restrictions on self-evidence and therefore attempted to justify belief in God by proofs of his existence. The reason such a project is mistaken is not simply that the New Testament itself offers no proof, and it is even more than the fact that the New Testament specifically mentions experiencing God as the basis for belief in his reality instead of offering proof. The further reason is nothing less than the most fundamental doctrine in Christianity, the teaching that God is the Creator of 'everything visible or invisible' (Col 1:16).

Taken at face value, this requires that God is the Creator of all the laws found in the cosmos, including the laws of proof - the laws of mathematics and logic. Since these are amongst the 'invisible' realities, they too are created But in that case, the laws of mathematics and logic do not account for their own origin. ${ }^{12}$ They are created laws that hold true for creatures and for God's self-manifestations in the cosmos. But since whatever can be proven by use of them must be governed by them, nothing that can be proven by using them could be their uncreated origin. Therefore proof of the reality of God's existence is impossible, because whatever can be proven would thereby not be God.

There is also another objection which the New Testament itself gives against arguments for God's existence: they cannot persuade anyone. It teaches that those who do not believe in God fail to do so because their hearts are already captive to another divinity belief. We noticed earlier that in Romans 1 St Paul describes unbelievers as those who regard something God created as divine instead of the true Creator. This means that the failure to believe in God is not merely a lack; it is not just a matter of the absence of a true belief. Rather it is a matter of seeing something else as possessing

12.There is a tradition of thought from Plato holding that a necessary truth does indeed account for its origin, since its necessity entails that it is self-existent. For example, Alvin Plantinga (2011:288) says that it is a 'widely shared intuition' that 'A proposition can't be a necessary truth without existing necessarily'. He's surely right not to give an argument for this point, as it would either be an egregious (a) ecessarly for its relata does not mean or entail that the relation is itself uncaused and unpreventable, because it does not rule out that the relata as well as their de re necessary relations are mutually correlated creations of God. 
divine status. It is some such false perception of divinity that makes ineffectual every evidence and argument for God's reality. Elsewhere, Paul puts it this way:

A natural man does not receive the things of the Spirit of God, they are folly to him and he is unable to know them for they are spiritually discerned. (1 Cor 2:14; emphasis added)

In other words: holding a false divinity belief is sufficient to prevent the acquisition of the true one unless God's Spirit enlightens the person holding the false belief. This is why no argument or assemblage of evidence for God's reality will ever seem convincing to those whose hearts are already captured by a different divinity.

The following analogy may help to make this last point clearer. If I look out my office window and see someone jump out from behind a bush and stab another person who then falls to the ground, I dial 911 and rush out to give first aid. But if I'm attending a magic show, and on stage I see someone stabbed and fall down I applaud with the rest of the crowd. I don't dial 911 and rush onstage to give first aid because my belief that what I'm seeing onstage is part of the show guides the beliefs I form about the events I see there. Confronted with the same events in both cases, I form utterly different beliefs about them. Just so, the New Testament position is that a person who believes in a putative divinity other than God will be guided by that belief in evaluating every piece of evidence and every argument for God's reality. The force of such arguments and evidences will thus be blocked by that false divinity belief in such a way that they will fail to convince the person of the truth of God's reality. Pascal (1960:198) saw this point clearly when he said: 'We will never believe ... unless God inclines our hearts. And we will believe from the moment he does so incline them'.

The conclusion, then, must be that offering arguments and proofs for God's reality is both wrong-headed and to no avail. Wrongheaded, because it demotes God to being a creature by subjecting him to the laws he built into creation. To no avail, because the heart captured by a false divinity belief cannot see the truth that God alone is the self-existent origin of everything visible or invisible.

This conclusion should not be disturbing despite the long history of Christian thinkers who mistakenly supposed God's existence either could be or needed to be proven. For all the while they were doing that, the New Testament declared that it is only the Spirit of God that can remove the blindness of heart that naturally afflicts all humans from birth, and that once God does that the people to whom it happens will see for themselves the truth of God's reality as self-evident. A paraphrase of this position is to say that although the human self-evidence antennae work well for truths of normal sensory perception, mathematics, logic, ethics, introspection, memory, and so forth, when it comes to what is divine our native equipment is faulty. Our antennae pick up something about the universe as the divine reality instead of its true Creator.

\section{Is this relativism?}

The fact that other religions make this same claim on behalf of their divinity beliefs troubles some Christians because they fear it will lead to relativism. If contrary beliefs have the same type of experiential ground, how can we prove which experience yields the truth? Won't we be forced to concede that every divinity belief is equally true? This fear is unfounded.

Whilst contrary experiences of self-evidence equally confer justification, they do not equally confer truth; intuitions of self-evidence are not infallible (we will see the reasons for this shortly).

In fact, there is a long-standing recognition of conflicting intuitions of self-evidence in mathematics and logic, for example Kline (1980) and Quine (1970). From the fact that people see different axioms to be self evident in mathematics, or disagree about the range of the application of axioms of logic, it doesn't follow that all those points of view are equally true. What does follow is that there is no neutral (non question-begging) way advocates of one point of view can prove their intuitions in such a way as to force them upon those with different intuitions of self-evidence. The two sets of disagreements are therefore alike in these respects, and we no more have neutral ground from which to prove our divinity belief to others than they have to prove theirs to us. This point naturally leads to questions about its consequences for Christian witness.

\section{Consequences for Christian witness}

What, then, of the presentation of the gospel to those who do not believe? Isn't this undercut by the admission that there can be no proof of it? Surely not.

Rather, it means that the way to approach non-believers with the gospel is not to attempt to argue them into belief but to challenge them to make an experiment in which they put themselves in a position to have a new and different experience. The experience to be sought is that of hearing God speak through his word, and the experiment is to undertake to read scripture (starting, say, with the gospel of John) and to precede each reading with the words: 'If you're really there, God, show me. ${ }^{\prime 13}$

The experiment should also include attending Christian worship as an observer, because seeing ordinary folk struggle with their understanding of the gospel is another way of exposing oneself to a new experience of it. After the experiment has been pursued for a while, it might also include reading some devotional and theological works as supplements. In all this, participants in the experiment need only assume that it is possible for them to have a different and belief-altering experience in which God speaks to them. If they won't admit this is even possible, then there's little

13.This is not begging the question or a sneaky way of getting the experimenter to assume God's reality. The words are purely hypothetical, and are spoken in case God exists. Any refusal to do this reflects a prior conviction that it's not possible that God exists and so prevents the experiment from being performed in good faith. 
point in the experiment. (But in that case I'd love to hear the reasons why it's supposed to be impossible.)

It is important that the reading-plus-worship-observation experiment be undertaken with the express purpose of hearing God speak. It is not to see if there is a coherent system of doctrine, an answer to a specific question, or merely to gather information. If the reading is done on the assumption that the gospel is a theory and the reading is undertaken to see whether holes can be picked in it, there's no doubt they can be found. If it's searched for inconsistencies, they'll turn up as well. But that sort of thing is beside the point. The point of the reading is to discover whether any cluster of its central teachings is experienced as the truth about God from God - which is hearing God speak.

Please notice that this experimental approach is nothing different from what we would recommend to a geometry student who couldn't see the truth of, say, the axiom 'things equal to the same thing are equal to each other'. Wouldn't we recommend using it to construct proofs and to see how it fits with other geometric truths? Wouldn't we compare its use to trying to do geometry without it? Wouldn't we recommend working on geometry along with others to see how they employ it? Such recommendations may or may not result in the student's seeing for him- or herself the axiom's self-evident truth, but it is the only way such a student could be put into a position to see it.

We should be prepared for those who would reply to the proposed experiment this way: 'I've already tried that experiment. I was raised in a Christian home and my parents took me to church. So I've often heard the scripture read and even had to memorise bits of it as a kid. So what would be the point of my doing it again?' Although this may sound reasonable, it's not.

Consider a parallel case. Suppose I'd been raised by parents who were big Shakespeare fans. Suppose, too, that they regularly took me with them to weekly meetings of a Shakespeare Society where I heard 10 or 20 lines of several different plays read aloud each week. On reaching adulthood, I conclude that I don't need any more exposure to know there's nothing special about Shakespeare. Is that a fair judgement? Of course not. I'd have reached it without reading any of his works from beginning to end, let alone all of them. My exposure would have been sporadic and piecemeal, and would lack all the background information that could make his plays come alive. What is more, I'd have heard those piecemeal readings prior to becoming an adult. In this way my early experience, despite having been spread over many years, was both immature and insufficient to justify my conclusion. These same points are even more apropos with respect to the Bible. In my experience, most of those who object to the experiment by saying they've already heard the scriptures read have not read them as adults, with guidance, and whilst listening for God to speak.

\section{Self-evident truth}

The traditional restrictions on the experience of self-evidence

We have already taken note that the Grand Masters of the Western intellectual tradition - Plato, Aristotle, and Descartes, amongst others - agreed on the question of how to distinguish beliefs that are merely opinions from beliefs whose certainty is justified. The consensus was: a belief counts as knowledge rather than mere opinion provided it is either self-evident or proven. Over the years since that consensus was formed there have been thinkers who have wanted to add beliefs arising from normal sensory perception to that list, or who have disputed one or even two of the traditional restrictions on self-evidence. ${ }^{14}$ But occasional dissent notwithstanding, the consensus on those restrictions has enjoyed remarkably wide acceptance. Of course, allowing that a belief is knowledge if self-evident or proven does not guarantee agreement on what those terms mean, and ever since this agreement was first reached (more than 2300 years ago) the debates over what 'proven' means have raged unabated. But self-evidence has largely been treated as a settled matter, and for that reason never got the critical evaluation it deserved. There isn't even an entry under that heading in the Encyclopedia of Philosophy, for example, and the prevailing view of it has never been systematically challenged en toto [all together].

I hope to end that right here and now. I will argue that the traditional restrictions on self-evidence: (1) presuppose a Naturalist divinity belief and thus beg the question against the self-evidence of God's existence, (2) are utterly unjustified, and that (3) there are excellent reasons to think every one of them is false. The restrictions lay down the requirements that to be genuinely self-evident a belief must not only be held as prima facie and irresistibly true without being inferred from any other beliefs, but must also be:

1. recognised as true by all who understand it

2. a necessary truth

3. an infallible truth.

Let's begin with the religious background to these restrictions. For both Plato and Aristotle the rational order of the cosmos was divine. For Plato that divine order was the Forms, for Aristotle it was rational (secondary) substances. Both thinkers therefore took a Naturalist position with respect to the divine, as both identified the mathematical and/or logical order of the cosmos as the divine reality. Moreover, both included in their definition of divinity not only that it is what exists independently (which is held by all religions), but also added that it is changeless (which not every religion agrees with).

These points all have to do with their divinity belief and their theory of reality, but both are important for their theory of knowledge. This is because both thinkers took the position that there must be a parity between reality and knowledge. In other words, they thought that what is most real must

14.For example, Russell (at one time) accepted sensory perception as self-evident and thus rejected the necessity requirement (Russell 1997:56). 
also be most knowable (most certain). Thus they wanted to restrict sure and certain knowledge to beliefs about those things that have the most certain (divine) existence. This led them to deny, for example, that normal sensory perception ever yields knowledge at all! For them, perception can only yield uncertain opinion because perceptions are changeable and thus non-divine. In contrast, the rational truths of logic, mathematics and certain ontological axioms are ones they believed to have independent existence and never change, and so are the only certainties.

Here's another way to put their point: the only beliefs we can be sure of are ones that can't change because what they are about can't fail to exist and can't change. So the mere fact that a belief is self-evident in the sense of being irresistibly prima facie true and not being inferred from other beliefs was not, for them, enough to make it a genuinely self-evident belief. On the contrary, they insisted that unless a belief also meets the three restrictions, and thus supports their rationalist commitment to the parity between divine reality and certain knowledge, it is to be rejected as genuinely self-evident belief.

To summarise: Aristotle allows only what is self-evident, or proven from self-evident beliefs, to be certain and then:

1. Allows only beliefs which are necessary truths (laws) to count as genuinely self-evident so that all seemingly selfevident beliefs concerning anything that is changeable are to be dismissed.

2. Declares that all self-evident beliefs about necessary truths are known infallibly (thus conflating certainty with infallibility).

3. Finally, takes the position that any genuinely self-evident truth will be recognised as such by every expert (rational thinker) in the field in which it arises (Topics 142a:9-10).

4. In this way he delivers to the Western tradition a tight package of restrictions concerning what is allowed to count as self-evident knowledge, a package whose contents are controlled by his divinity belief: self-evident knowledge is what all rational experts believe about the rationally necessary truths which are guaranteed to be infallible because they are immutable rational principles (Aristotle 1941).

The curious thing about this reductionist view of selfevidence is that Aristotle nowhere argues for it! It's what he wanted to be true, so he simply declared it to be so. Whilst he gives examples of instances of self-evident mathematical or logical truths which are also necessary truths and which were agreed on by all the experts he knew, he nowhere gives any reasons to suppose that all self-evident truths must be like the examples he gives. Moreover, as we will shortly see, these restrictions have absolutely nothing to recommend them other than his wishful thinking.

For this reason the extent to which even thinkers who didn't share his divinity belief have bought into his restrictions anyway is truly amazing. This includes Descartes, who not only endorsed Aristotle's restrictions but contributed to them. It was Descartes's proposal to expand on restriction three - the one that says all experts will recognise a genuinely self-evident truth. It's not just the experts, says Descartes, but anyone 'in the least degree rational' will recognise a genuinely self-evident truth provided that he understands it (Descartes 1958:6-10). It is Descartes's democratised version of this restriction that came to be regarded as the very hallmark of self-evidence by the 20th century.

My critique of these traditional restrictions begins from the standpoint that self-evidence is an experience. The notion that self-evidence is a property of a proposition (or of a belief) is only part of the truth about it. It can also be the property of things directly experienced whether or not we ever form a proposition about them. Moreover, in order to be 'evident', a belief must be evident to someone. It makes no sense to say that a belief is evident in itself, for 'evident' is an 'intentional term' - a term that connotes a relation requiring both a subject and an object. For example, it makes no sense to say that something is seen though no one sees it, just as it makes no sense to say someone hears if that person doesn't hear anything. In the same way, it makes no sense to say that something is evident unless there is someone to whom it is evident. ${ }^{15}$ Moreover, both the truth of a self-evident belief and its recognition also depend on an even wider relation to the rest of reality. 'This class is now in session' is self-evident to those in the class, but once the class is over it becomes self-evidently false. Finally, a person's ability to recognise self-evidence is also relative to his or her prior information, skills and mindset. A hunting guide sees game where a tenderfoot sees nothing.

For these reasons, self-evidence needs to be understood as an experience and that experience needs to be described. So here, again, is my proposal for its definition:

A belief, B, is self-evident to a person, $\mathrm{P}$, if and only if:

1. B is directly produced in P by experience and is not believed by inference from other information

2. B is experienced by $\mathrm{P}$ as prima facie true

3. B is initially irresistible to $P$.

Item one recognises that self-evident beliefs have in common that they are simply produced in us by some experience rather than being inferred from other information. By 'experience' I mean (for now) the ordinary and reliable modes of acquiring information ${ }^{16}$ such as normal perception, memory, introspection, or rational reflection, regardless of the particular object of the experience.

We all form beliefs every day which are produced in us by each of these reliable modes of experience, and many of them have the quality of self-evidence because they satisfy the three conditions mentioned above. An example of a self-

15.This does not rule out, however, that a belief can be self-evident but remain subconscious or unconscious.

16.It was Alston (1991) who introduced the notion that justification must start with our doxastic practices rather than with beliefs taken individually. 
evident belief produced by perception is your belief that the words you are now seeing are really before you. You are not inferring their existence from other information; rather, your experience of seeing them is directly producing in you the belief that they are really there. Self-evident memory beliefs include your name, address and telephone number. The experience of remembering them reactivates in you those beliefs in a direct way that differs from inference. Likewise, you can introspect and find that you are tired or there's an ache in your back or whatever. Such introspective beliefs are also simply produced in you rather than being conclusions at the end of a chain of reasoning. Finally, there are beliefs that arise just from reflecting upon something - the sort of experience many thinkers have called 'rational intuition'. For example, you can think of $1+1=2$ and just 'see' that in the natural number series it is necessarily true. None of these sample beliefs are arrived at via a process of reasoning from other information; rather they are produced in you by one or another normally reliable mode of experience. ${ }^{17}$

Item two calls attention to the fact that all the examples given in the previous paragraph are ones we experience as prima facie true. Their truth is not a guess (hypothesis), nor is it suggested by other beliefs or believed on the recommendation of other people; in each case the beliefs themselves look glaringly true.

Item three asserts that such beliefs are ones we find to be irresistible. This means that when we initially form them we can't get ourselves to disbelieve them. ${ }^{18}$ It doesn't mean they can't ever change or be rejected; in fact, everyone spontaneously and regularly checks on them in a number of ways. One way is that they are checked against other self-evident and well-established beliefs. For example, if I look out the window and see that it's raining, it instantly becomes impossible for me to disbelieve it's raining. But if I then notice a group of laughing friends gathered around holographic equipment that is projecting a rainstorm onto my window, I can reject the first experience of self-evidence by comparing it to this second one. People normally also check their self-evident beliefs with those of others, and at times reflect upon how well a self-evident belief comports with their overall experience or upon whether it helps to make sense of it. Finally, self-evident beliefs can also be rejected in response to a change in the experience of selfevidence. In sum: the initial irresistibility of a belief can grow over time by being tested and confirmed, just as it can be diminished or lost by being disconfirmed.

17.This is not to deny that unusual experiences can also produce beliefs which are prima facie and irresistibly true, but for now I'm thinking only of the intuition of self evidence as it attaches to ordinary sorts of experiences which are unquestionably reliable doxastic practices (perception, memory, introspection and rational reflection). More specifically, I am speaking of the self-evidence attaching to the experience of reflecting on the gospel that was chosen because it is the only type of religious experience common to all believers in God.

18.This is a point on which Descartes led the Western philosophical tradition astray by construing a self-evident belief as one we are unable to doubt. But doubt is not the opposite of certainty, disbelief is. And what Calvin says about belief in God applies opposite of certainty, disbelief is. And what Calvin says about belief in God applies
to many other self-evident beliefs as well: $\quad . .$. we speak not of an assurance which is never affected by doubt, nor a security which anxiety never assails, we rather is never affected by doubt, nor a security which anxiety never assails, we rather
maintain that believers have a perpetual struggle with their own distrust' (Calvin maintain that beli 1 :ii, 17).
Please notice that there are several things people often associate with self-evidence that I've deliberately excluded from this description.

For one thing, I did not say that a self-evident belief is one that must be seen to be true immediately upon understanding it (some are, some are not). ${ }^{19}$ Nor did I say that seeing a truth as self-evident doesn't ever require training, reflection, or comparison and judgement. Reflection and comparison are also experiences, and they are indispensable accompaniments to the experience of self-evidence. For example, many years ago I learned to tune pianos. It took an apprenticeship of ear training for me to learn to hear whether a tone was sharp or flat compared to another. But now that I have learned how to do that, it is self-evident to me whenever one pitch is out of tune with another.

This last example also serves to dislodge another mistake that is often assumed about self-evidence: namely, the idea (rejected earlier) that it takes no background information or conditioning to apprehend a self-evident truth. Not so. A striking example of this point is given by Tobias Danzig, who tells of a tribe in Africa whose language contained only words for one, two, and many (Danzig 1954:5). Without the concept and word for 4 it couldn't be self-evident to those people that $2+2=4$, whilst for those who have been initiated into arithmetic the judgement $2+2=4$ is as self-evident as anything can be.

Since seeing the self-evidence of a belief does not exclude reflection or comparison, and since it need not happen instantaneously, there is no inconsistency in my now claiming that parts two and three of the description of 'self-evident' are themselves self-evident. You need only to compare them to your own experiences of self-evident beliefs to confirm their accuracy, and comparing them to your experiences won't disqualify them as genuinely self-evident. It is on that basis that it is self-evident to me that the parts of the description are indeed elements of those beliefs. But I mean by this that the description fits them as we actually experience them, aside from the restrictions placed on them by Aristotle and Descartes - the restrictions that rule out belief in God.

So what are we to make of those restrictions? If genuine knowledge consists of beliefs that are self-evident or proven, as they thought, then surely it is fair to ask whether their restrictions are self-evident or proven. That is the question which has never been asked over the many centuries of their nearly universal acceptance. But it must be asked. For if their restrictions are neither self-evident nor proven, then they cannot count as knowledge, given their own definition of knowledge.

\section{A critique of the traditional restrictions on self-evidence}

\section{Critique: Everybody Requirement (first restriction)}

I'll begin with the restriction insisted on by Descartes, and now widely accepted as the very definition of 'self-evident'.

19.Aquinas (1960:38) did say that everyone recognises a self-evident truth 'at once' upon understanding it. 
It is what I call the everybody requirement. It says that for a belief to be genuinely self-evident, every person who is 'in the least degree rational' and understands the statement of it must see it to be self-evidently true (Descartes 1958:6). This has often been used to reject the self-evidence of God's reality. For example, Anthony Quinton has tried to argue that intuitions of the self-evidence of logical truths are genuine because everyone agrees with them, whilst that is not true of claims of moral and mystical (religious) selfevidence. Quinton (1973) says:

What is significant is the fact of universal agreement, amongst all but the muddled or deliberately perverse, that a particular set of beliefs are true. Every proposition has been disputed by somebody. But the dialectician who claims to deny the law of contradiction is insincere ... It is the failure of this ... requirement of universal agreement that undermines the claims of moral and mystical intuition. (p. 125)

Notice that Quinton first claims there is a set of beliefs that are universally agreed upon, but that the set then turns out to have only one member. He also admits that even this single 'universally agreed upon' belief actually has dissenters ('every proposition has been disputed by somebody') and so is not universally agreed upon! To compound his felony, he then dismisses those who disagree by substituting namecalling ('muddled or insincere') for argument. In doing so, he wilfully ignores not just a few muddled minds but the entire tradition of Hindu and Buddhist mystics who have for millennia denied his candidate for universal acceptance so that his dismissal of them begs the question.

So what can be said in favour of this restriction when it's clear that not even the law of non-contradiction can satisfy it? Can it be defended? More specifically, can the restriction itself be proven or qualify as self-evident? Let's start with whether it can be proven.

There is an initial difficulty with this restriction that makes its proof problematic in excelsis: How could we ever discover that any belief at all meets the requirement? You see, 'everybody' cannot mean just those now living; it has to mean all human beings no matter when they lived or will live. So even if we could discover that every person on earth now sees a particular belief to be self-evidently true, that would tell us nothing about whether all the dead also believed it to be true or whether all the unborn will agree with it in the future. For this reason we cannot discover, for any particular belief, whether it meets the requirement. But if we cannot tell for any belief whether it has this characteristic, there is no way to prove that all self-evident beliefs must have it. For the restriction to be correct it would have to be universally true in order to be necessarily true. So if we can't discover that universal acceptance is in fact true of any self-evident beliefs, there is no way to show it is true of all of them. In that case this restriction cannot be proven to be a genuine requirement for a belief to be self-evident.

Let me put this same point in another way. The inaccessibility of what people believed in the past or will believe in the future is not merely a practical snag, but is fatal to any inductive evidence in favour of this restriction. Since we can't survey everyone, no belief whatever can be known to meet its requirement. Therefore there can be no evidence that the Everybody Requirement applies to any self-evident truth, let alone to every one of them. But if we can't know that all beliefs experienced as self-evident in fact have this characteristic, then we're in no position to argue that they all must have it. Nor can we gather information that would give us premises from which to infer deductively that the requirement is genuine. Hence this restriction is not merely in fact unproven, but is unprovable in principle. Therefore, if it is to qualify as knowledge, the everybody requirement must itself be self-evident. Is it?

The answer is 'no', because it is not self-evident to me.

I am not alone in that respect, but even if I were, the restriction would still fail its own requirement for self-evidence. Thus it is hoist with its own petard. And since it is neither selfevident nor proven, it is not knowledge but mere opinion.

Perhaps this shouldn't be too surprising. After all, if correct, the everybody requirement would rule out the self-evidence of such beliefs as: these words are now before you; there are real objects external to you; other people have minds; and your name, address and telephone number. The surprising thing is not that this restriction fails, but that it was ever taken seriously. But taken seriously it certainly was! Since the time of Descartes, dozens of the best minds have tried for centuries to prove that there are really objects around us, that other people have minds, and that God exists. And the only reason they thought such proofs were needed was that the self-evidence of those beliefs had been ruled out by this restriction and its companions.

\section{Critique: Necessity Requirement (second restriction)}

The next restriction, one proposed by Aristotle, insists that to be genuinely self-evident a belief must be a necessary truth. That means it must be a law of some kind, that is, a truth that either cannot be conceived to be false or which cannot be altered by any power or change of circumstances in the cosmos. Here are some examples of necessary truths: $1+1=2$; things equal to the same thing are equal to each another; nothing can appear red and green all over at the same time; all bachelors are unmarried; and $79 \times 125=9875$. (Please notice that since it is not a necessary truth that these words are before you, that there are objects around you, or that other people have minds, this restriction rules out the self-evidence of those beliefs every bit as much as did the 'everybody' requirement.)

Now many (but not all) necessary truths are known because their necessity is self-evident; that is, you can just 'see' not only that they are true but that they cannot be made false by any conceivable change in circumstances. $1+1=2$ is an example. But the fact that many necessary truths are known because they are self-evident is not what is at stake here. 
What is in question right now is different. It's whether only necessary truths can be self-evident. So let's now do what we did with the Everybody Requirement, and ask whether the Necessity Requirement is itself self-evident or proven. We start with whether it's self-evident. To know whether it is self-evident, we would first have to know whether the restriction meets its own requirement. That is, we must know whether it's a necessary truth that all self-evident beliefs must be necessary truths. Is that self-evident?

There is an insurmountable difficulty with asserting that it's self-evident the restriction meets its own requirement: the claim is hopelessly circular. We would have to know that the requirement is a necessary truth in order to know it is selfevident, and we'd need to know it is self-evident to know it is a necessary truth! So although it must be both or neither, we are left with no way of telling which. As a result, the necessity requirement cannot itself be known on the grounds that it is self-evident. So can its own necessity be proven?

No one has ever even tried to offer a proof that this restriction is true - or even that it meets its own requirement.

Think of that. No proof has even been attempted in the more than 2300 years since it was proposed! No doubt that's because it's hard to imagine what a proof of it could possibly look like. What could serve as undoubtedly true premises from which to deduce this restriction? How could any proposed premises for it be so undeniable as to make us give up the experienced self-evidence of such a (non-necessary) belief as that these words are now before you? No doubt it is obstacles such as these which have prevented attempts at proving this restriction. The fact that no one has ever deduced it from other premises isn't conclusive, however, because there is yet another way to argue that a belief is a necessary truth. The other way consists of showing it has a self-contradictory denial. Here's what that means.

Take the statement: 'All bachelors are unmarried.' To deny that, we'd have to assert: 'Some bachelors are married.' Is the concept of a married bachelor self-contradictory? Surely it is. But if 'some bachelors are married' contradicts itself, that constitutes a proof that 'All bachelors are unmarried' is a necessary truth. Here's another example: 'No circles are squares.' To deny this we must affirm: 'There is at least one circle that is also a square.' Is a square circle an absurd self-contradiction? It sure is. And in that case 'No circles are squares' is proven to be a necessary truth.

Now try this same test with the Necessity Restriction on self-evidence. Here is its denial: 'There is at least one selfevident truth that is not a necessary truth.' Is that patently self-contradictory in the way married bachelors or square circles are? Is it an absurd contradiction to think that it's self-evident that the words you are now seeing are really before you? Of course not! There is not the slightest reason to think that if you deny the restriction you contradict yourself. But if the Necessity Restriction cannot be proven from other premises to be a necessary truth, and if it cannot be shown to have a self-contradictory denial, then it cannot be proven to be a necessary truth at all.

Since we have already seen why its necessity can't be selfevident, the conclusion must be that this requirement is neither self-evident nor proven. Thus it, too, is hoist on its own petard every bit as much as is the Everybody Requirement. They are both in the same (sunken) epistemological boat. Neither of them has any proof, and each fails to meet its own requirement for being self-evident. Therefore on the view of knowledge advocated by the proposers of these restrictions, they cannot be knowledge but are mere opinions.

\section{Bad opinions.}

Bad because the evidence against both restrictions persists in everyone's experience all day every day. That evidence consists of the beliefs which are experienced as self-evident but which do not meet the 'everybody' or 'necessity' requirements. Once again, these beliefs include such examples as perceptual beliefs (there are objects around us, including these words which you now see), memory beliefs (our names and addresses), introspective beliefs (that you have a slight headache). There are also a myriad self-evident beliefs produced by rational reflection: the belief that $1+1=$ 2 and that being circular excludes being square, for example.

\section{Critique: Infallibility requirement (third restriction)}

The last of the three restrictions on what is allowed to count as self-evident is also from Aristotle and was repeated by Descartes. It is the Infallibility Requirement. This restriction requires that to be genuinely self-evident a belief must be infallibly true (Aristotle 1941:113; Descartes 1958:10).

Please do not confuse infallibility with certainty. For a belief to be infallible it would have to be impossible for us to be wrong about it, and we do not have to be infallible to be certain of something beyond a reasonable doubt.

No doubt you are certain that the words you are reading right now are really before you, and you are justified in that certainty because their existence is self-evident to you. But that doesn't mean that it's impossible for you ever to be mistaken about anything you see, so you are not acquiring that belief by means of an infallible capacity. Understand, then, that the infallibility requirement is an extremely strong claim. It means that all genuinely self-evident beliefs must be ones that could not possibly be false under any circumstances. If a belief is formed by a capacity of ours that can ever be mistaken, or if there is any conceivable circumstance under which it could be false, it is not an infallible belief.

There are several things amiss with this restriction.

Firstly, there is a broad, general objection to this requirement that stems from an attitude engendered by our Christian heritage. That attitude warns us against 'thinking of 
ourselves more highly than we ought to think' (Rm 12:3). The objection begins by asking ourselves: What would ever tempt us to suppose we have any belief-forming capacity that is infallible? To this question there is, in Genesis, a scary answer. For Genesis records that the fall into sin occurred when human beings caved in to the temptation of wanting to be divine! Keep in mind that the temptation was not simply to eat forbidden fruit. Rather it went like this: 'If you disobey God, you will know good and evil just as he does'. So there is something very sinister about being tempted to think there is any capacity we have for knowing as God does - for having knowledge that is infallible.

Consider this: our perception is generally reliable but not infallible; our memories are generally reliable but not infallible; introspective beliefs are likewise reliable but not infallible, and our reasoning is generally reliable but not infallible. What good reason can we have, then, to suppose that our capacity to intuit self-evident truths is any different? Since we can still be justifiably certain of a belief without being infallible, let's leave infallibility to God.

Secondly, this restriction can't be defended by claiming it's self-evident because that would involve the same vicious circularity we found to be the case for claiming the necessity requirement is self-evident. We would have to know the restriction to be infallible to know it is self-evident, and we would have to know it is self-evident to know it is infallible. Thus it could be neither just as well as it could be both, and we are left with no way to decide.

Finally, there is also no proof for this restriction. In this case, too, no one has ever so much as attempted an argument to show that every genuinely self-evident belief must be infallible, and once again I doubt anyone can even imagine what such a proof would look like. The reason for that doubt is that there seems to be a conceivable set of circumstances under which almost any belief, no matter how certain it seems, could possibly be mistaken. Take, for example, the belief that $1+1=2$. Wouldn't that look just as true if Alpha Centaurians were bombarding our brains with Tachyon waves so as to make it look certain when it is really false? (Notice that a set of circumstances doesn't have to be real to defeat the infallibility of a belief; it needs only to be conceivable.) The conceivable circumstance that some force is controlling your brain so as to make you believe that $1+1=2$ or that the words you're now seeing are really before you is enough to show that you don't know those things infallibly.

This last point all by itself is enough to defeat the infallibility of the infallibility requirement. Ask yourself: Is the belief 'all genuinely self-evident truths must be known infallibly' itself an infallible truth? The answer can only be 'no' because even if it looks true to you, it could still be false if some force were controlling your mind to make it look true. So this restriction also fails to meet its own requirement. As with the necessity requirement, it is therefore neither self-evident nor proven.

Some readers may be tempted to object at this point that there surely are some beliefs that are infallible, namely the ones we call 'incorrigible' beliefs - beliefs about how our own internal states seem to us that just could not be false. This is surely right. We can't be mistaken that, for example, our head seems to hurt, even if it were only because Alpha Centaurians were making us think so. But such beliefs are still not formed by a capacity that is infallible. They are formed by introspection, which is notoriously fallible - when it comes to our own motives, for example. Moreover, even incorrigible beliefs involve judgement, and we do at times revise those judgements. I may tell you in all sincerity that I have a headache but on later reflection come to believe that what I really experienced was a toothache. These examples don't undermine the point that we have beliefs about how things seem to us at a particular time that are (taken individually) unfalsifiable even if acquired by a fallible capacity.

But the fact that there are such beliefs doesn't show much. All it shows is that a very limited class of beliefs about how our internal states seem to us cannot be wrong. That, however, doesn't give us the slightest reason to suppose that all genuinely self-evident beliefs must be like them, or that they alone are the only genuinely self-evident beliefs. Moreover, there is keen irony in the fact that incorrigible beliefs, which are the best candidates for infallibility, necessarily fail the 'everybody' and 'necessity' requirements!

\section{Conclusion}

The conclusion is obvious. None of the restrictions can count as self-evident, and none of them has any proof. Furthermore, none of them meets either its own requirement or the requirements of its companion restrictions. The conclusion must be that none of them is justified. They are but unsupported opinions.

Moreover, they are opinions held in the face of the implacable fact that they are at odds with everyone's experiences of self-evidence every day. They are, therefore, amongst the most unwarranted influential proposals ever to burden an intellectual tradition. There is not the slightest reason for allowing them to overrule everyone's experiences to the contrary. Rather, they should be dismissed with prejudice, and the Grand Masters of our intellectual tradition should no longer be allowed to dictate from on high what they will permit us to count as self-evident. It is time that self-evidence be understood from the bottom up rather than from the top down. It should be understood from the reports of what people in fact experience to be self-evident, not from what a few philosophers wish it to be. If we do that, not only will such beliefs as those of the reality of objects around us - along with our names, addresses and telephone numbers, that other people have minds, and that the words you now see are really there - turn out to be self-evident; so will the belief that God is real for those who experience that as self-evident.

The upshot is that self-evident knowledge is justified belief and is sufficient for certainty beyond a reasonable doubt despite the fact that it does not entail truth. Thus contrary beliefs may be equally justified to different people 
owing to their differing experiences of self-evidence. That conclusion is contrary to the rationalist tradition, but it is not irrationalism or total relativism when viewed from a Theistic standpoint. It is less than rationalism has wanted, but is realistic about our human condition; it is the actual state of affairs for our knowledge of the entire spectrum of human experience. We simply are not the embodiments of neutral, divine rationality that Plato and Aristotle wished us to be.

Thus there is simply no good reason to dismiss as spurious the experience of billions of people who find it self-evident that the gospel is the truth about God from God. On the contrary, they are as entitled to be as certain of that as you are that these words are now before you.

\section{Acknowledgements Competing interests}

The author declares that he has no financial or personal relationship(s) that may have inappropriately influenced him in writing this article.

\section{References}

Alston, W., 1991, Perceiving God, Cornell University Press, New York.

Aquinas, T. (ed.), 1960, Thomas Gilby: St Thomas Aquinas philosophical texts, Oxford University Press, New York.

Aristotle, 1941, 'Metaphysics' in Aristotle, in R. McKeon (ed.), The basic works of Aristotle, pp. 1005 b 12, 1006 a 8-10 Random House, New York.
Aristotle, 1941, 'Posterior analytics' in Aristotle, in R. McKeon (ed.), The basic works of Aristotle, pp. 70 b 9-12, 73 a 21-22, 74b 5, 23-26, 75 a 18, 31-31, 88 b 30-89 a 10; 100 , b 5-12 Random House, New York.

Aristotle, 1989, Topica, transl. E.S. Forster, Harvard University Press, Cambridge.

Barker, S., 1974, The elements of logic, McGraw Hill, New York.

Calvin, J., 1953, Institutes of the Christian religion, Eerdmans Publishing Co., Grand Rapids.

Clouser, R., 1997, 'A critique of historicism', Critica XXIX(85), April, 41-63.

Danzig, T., 1954, Number: The language of science, Doubleday Anchor, Garden City.

Descartes, R., 1958, Descartes' philosophical writings, N.K. Smith (ed.), The Modern Library, New York.

Delitzsche, F., 1952, Commentary on the epistle to the Hebrews, Wm. B. Eerdmans Publishing Co., Grand Rapids.

Hill, R., 1998, On Beulah Height, Dell Publishing, New York.

James, W., 1929, The varieties of religious experience, Dell Publishing, New York.

Kline, M., 1980, Mathematics: The loss of certainty, Oxford University Press, New York. Locke, J,. 1959, Concerning human understanding, Dover Publications, New York.

Luther, M., 1854, 'An introduction to Paul's letter to the Romans', in J. Irmischer (ed.), Dr. Marin Luther's vermischte Deutche schriften, vol. 63, p. 125, transl. R. Smith, Heyder and Zimmer, Erlangen.

Luther, M., 1959, The Larger Catechism in the Book of Concord, Fortress Press, Philadelphia.

Nagel, E., 1954, Sovereign reason, Free Press, Glencoe.

Pascal, B., 1960, Pensees, L. LaFuma (ed.), transl. J. Warrington, J.M. Dent \& Sons Ltd., London.

Pelikan, J., 1992, Christianity and classical culture, Yale University Press, New Haven.

Plantinga, A., 2011, Where the conflict really lies, Oxford University Press, New York. http://dx.doi.org/10.1093/acprof:oso/9780199812097.001.0001

Quine, W.V., 1970, Philosophy of logic, Prentice Hall, Engelwood Cliffs.

Quinton, A., 1973, The nature of things, Routledge \& Kegan Paul, London.

Russell, B., 1997, Properties, D.H. Mellor \& A. Oliver (eds.), Oxford University Press, Oxford.

Streeter, B.H. \& Appasamy, A.J., 1921, The Sadu, Macmillan, London. PMid:16015908

Wittgenstein, L., 1972, On certainty, G.E.M. Anscombe \& G.H. von Wright (eds.), transl. D. Paul \& G.E.M. Anscombe, Narper \& Row, New York. 